\title{
MOTIVASI BERKUNJUNG DAN PERSEPSI WISATAWAN NUSANTARA TERHADAP KUALITAS PELAYANAN DI TOYA DEVASYA DESA BATUR KINTAMANI
}

\author{
I Gede Wiramatika $^{1}$, Ni Putu Eka Mahadewi ${ }^{2}$, Ni Gusti Ayu Susrami Dewi ${ }^{3}$ \\ ${ }^{1}$ Email : wiramatika93@gmail.com \\ Program Studi SI Industri Perjalanan Wisata, Fakultas Pariwisata, Universitas Udayana \\ ${ }^{2}$ Email : eka.mahadewi23@gmail.com \\ Program Studi SI Industri Perjalanan Wisata, Fakultas Pariwisata, Universitas Udayana \\ ${ }^{3}$ Email : susrami_ipw@unud.ac.id \\ Program Studi SI Industri Perjalanan Wisata, Fakultas Pariwisata, Universitas Udayana
}

\begin{abstract}
This research observed the Toya Devasya, Kintamani. The aim of this research are 1) to know the motivation of domestic tourist's that visit the Toya Devasya Kintamani, Bangli. 2) to know their perception in regards of its service quality. This research used sample determination method which tend to purposive with taking its sample by using accidental sampling method and determining the number of samples using quota sampling giving 100 questioners to domestic tourist. Data collection technique that used is by interview, observing, documentation, literature study and questioner with analysis technique by qualitative and quantitative descriptive. The result showed the motivation which push domestic tourist's to visit Toya Devasya are to make the mind calm, relax and free yourself in a beautiful and interesting place, get a new atmosphere. At the same time the motivation that pull those tourist's to visit Toya Devasya is the beauty of natural mountain kicking, a nice atmosphere to be enjoyed, the source of hot water coming from Mount Batur. The perception of domestic tourist's to its service quality over all is good, however they still feel that the lack of assurance service in Toya Devasya.
\end{abstract}

Abstrak: Penelitian ini dilakuakan di daya tarik wisata tirta pemandian air panas Kintamani. Penelitian ini bertujuan 1) untuk mengetahui motivasi wisatawan nusantara yang berkunjung ke daya tarik wisata tirta pemandian air panas di Kintamani. 2) untuk mengetahui persepsi wisatawan nusantara terhadap kualitas pelayanan daya tarik wisata tirta pemandian air panas di Kintamani. Penelitian ini mengunakan metode penentuan sampel yang dilakukan secara purposive dan pengambilan sampel secara Accidental Sampling dengan mengguanakan kuota sebanyak 100 responden wisatawan nusantara. Teknik pengumpulan data yang digunakan adalah wawancara, observasi, dan kuesioner dengan teknik analalisi data secara deskriptif kualitatif dan deskriptif kuantitatif. Hasil dari penelitian ini menunjukan bahwa motivasi yang mendorong (push factor) wisatawan nusantara untuk berkunjung ke Toya Devasya adalah untuk membuat pikiran menjadi tenang, bersantai dan membebaskan diri di tempat yang indah dan menarik, mendapatkan suasana baru, melakukan hal baru yang berbeda dari kegiatan sehari-hari. Sedangkan motivasi yang menarik (pull factor) wisatawan nusantara untuk berkunjung ke Toya Devasya adalah keindahan pemendangan alam pegunungan, suasana yang bagus untuk dinikmati, sumber air panas yang berasal dari gunung Batur, tertarik dengan keindahan pemandangannya, healing SPA. Persepsi wisatawan terhadap kualitas pelayanan secara keseluruhan sudah baik, namun wisatawan merasa kurang pada pelayan Assurance yang ada di Toya Devasya.

Keywords: motivation, perception, tirta tour, natural hot spring. 


\section{PENDAHULUAN}

Bali merupakan salah satu destinasi wisata yang dikenal baik mancanegara maupun di nusantara. Keindahan alam, budaya yang unik serta keramahtamahan penduduknya menjadikan Bali berbeda dengan pulau lainnya di Indonesia dan secara tidak langsung menarik minat wisatawan untuk berkunjung ke Bali. Sebagai destinasi berskala internasional, Bali melalui sektor pariwisata terus berupaya untuk memelihara dan melestarikan segenap potensi yang dimiliki serta selalu berusaha untuk meningkatkan kualitas pelayanan yang diberikan kepada wisatawan sehingga mereka senang dan tinggal lebih lama di Bali. Secara administrative Bali terbagi ke dalam tujuh Kabupaten dan satu Kota Madya. Setiap Kabupaten di Bali mempunyai keunikan tersendiri antara satu dengan yang lainnya. Salah satunya adalah Kabupaten Bangli. Bangli memiliki sejumlah destinasi wisata yang terkenal baik dalam lingkup Nusantara bahkan sampai ke Mancanegara. Salah satu kawasan wisata di Kabupaten Bangli yang sudah sangat dikenal baik di dalam negri maupun di luar negri adalah wisata Kintamani.

Kintamani yang memiliki beberapa daya tarik wisata alam seperti, Gunung Batur dan Danau Batur, sebagai daya tarik wisata Pura Batur, daya tarik wisata Pura Penulisan, daya tarik wisata Desa Kedisan, daya tarik wisata Desa Trunyal, serta daya tarik wisata tirta pemandian air panas alami Toya Bungkah. Wisata tirta salah satu daya tarik yang dewasa ini menjadi primadona bagi wisatawan nusantara, salah satu banjar yang saat ini berkembang sebagai daya tarik wisata tirta adalah Toya Bungkah yang berada dibawah pengelolaan Desa Pekraman Batur.

Daya tarik wisata tirta permandian air panas di daerah Toya Bungkah sendiri memiliki beberapa pemandian air panas seperti salah satunya adalah Toya Devasya. Toya Devasya menawarkan perpaduan kolam air panas dengan Danau
Batur sebagai pemandangannya yang dimana dapat menikmati pemandangan Danau Batur dan Gunung Batur sambil menikmati air panas dengan udara yang sanat segar, selain itu Toya Devasya juga menyediakan fasilitas-fasilitas seperti kolam renang, kolam berendam dengan air panas, SPA, restaurant, hotel, loker, ruang ganti yang mampu menarik minat wisatawan untuk berkunjung. Toya Devasya yang dikelola oleh perseorangan hingga saat ini masih terus melakukan penataan-penataan diharapkan mampu memberikan kepuasan kepada wisatawan yang berkunjung.

Toya Devasya merupakan daya tarik wisata tirta pemandian air panas ini terletak di Kawasan Wisata Kintamani yaitu di Desa Pekraman Batur, Kecamatan Kintamani, Kabupaten Bangli. Tepatnya teletak di pinggir Danau Batur dengan jarak lebih kurang 90 kilometer, dari Bandara Ngurah Rai, dapat ditempuh dengan kendaraan sekitar 2,5 jam dari kota Denpasar. Daya tarik wisata tirta pemandian air panas ini merupakan salah satu healing spa dari beberapa yang ada di Pulau Bali. Kandungan belerang yang sangat tinggi terdapat di dalam airnya dan air yang sangat jernih yang memiliki kehangatan $39^{\circ}-40^{\circ} \mathrm{C}$ dengan kehangatan yang menetap karena air yang terus mengalir sepanjang waktu dan bersumber dari gunung Batur, yang dipercaya dapat mengembalikan tenaga dan menyembuhkan berbagai jenis penyakit kulit dan dilengkapi dengan fasilitasfasilitas yang tidak kalah dengan fasilitas yang ada di wisata tirta yang lainnya, serta pemandangan perpaduan kolam dengan danau Batur dengan berlatar belakang perbukitan yang sangat bagus dan tidak ada duanya. Tarif masuk yang dikenakan kepada wisatawan nusantara adalah sebesar Rp75.000; untuk pengunjung dewasa dan untuk anak-anak sebesar 50\% dari tarif orang dewasa atau Rp35,000.

Wisata tirta pemandian air panas sebagai salah satu daya tarik wisata yang dimiliki di Kintamani yang semakin 
banyak diminati oleh wisatawan nusantara. Hal ini terbukti dari data jumlah kunjungan wisatawan ke dua daya tarik tersebut, seperti yang terlihat pada tabel 1 berikut.

Tabel 1. Data Kunjungan Wisatawan Nusantara ke Daya Tarik Wisata Tirta Kintamani

\begin{tabular}{|c|c|}
\hline Tahun & $\begin{array}{l}\text { Jumlah Kunjungan } \\
\text { Wisatawan Nusantara } \\
\text { ke Toya Devasya }\end{array}$ \\
\hline 2012 & 7.344 \\
\hline 2013 & 8.344 \\
\hline 2014 & 9.511 \\
\hline 2015 & 11.981 \\
\hline 2016 & 115.305 \\
\hline Rata-rata & 30.497 \\
\hline
\end{tabular}

Terlihat pada tabel 1 mengenai data kunjungan wisatawan Nusantara yang berkunjung ke daya tarik wisata tirta pemandian air panas kintamani dari tahun 2012 sampai 2016. Toya Devasya pada lima tahun terakhir ini, dari 2012-2016 rata- rata kunjungan wisatawan Nusantara pada setiap tahunnya sebanyak 30.497 wisatawan Nusantara yang berkunjung ke Toya Devasya. Pada tahun 2013 jumlah kunjungan wisatwan mengalami peningkatan sebanyak 1.000 dari tahun 2012. Jumlah kunjungan wisatawan pada tahun 2014 mengalami peningkatan sebanyak 1.167 dari tahun 2013. Berlanjut ke tahun 2015 jumlah kunjungan wisatwan juga mengalami peningkatan sebanyak 2.470 dari tahun 2014. Tahun 2016 peningkatan jumlah kunjungan wisatwan yang sangat drastis yaitu sebanyak 103.324 dari tahun 2015. Secara keseluruhan jumlah kunjungan wisatawan yang berkunjung ke Toya Devasya pada lima tahun terakhir selalu mengalami peningkatan.

Melihat jumlah kunjungan wisatawan nusantara yang selalu meningkat ke daya tarik wisata tirta pemandian air panas kintamani pada setiap tahunnya, kelengkapan fasilitas dan keunikan dibandingkan dengan daya tarik wisata tirta yang lainnnya maka peneliti tertarik untuk mengangkat wisata tirta pemandian air panas Kintamani sebagai topik penelitian. Adapun permasalahan yang diangkat antara lain mengenai motivasi dan persepsi wisatawan nusantara terhadap kualitas pelayanan daya tarik wisata tirta pemandian air panas kintamani sebagai daya tarik wisata air panas di Toya Bungkah Kintamani. Penelitian ini penting dilakukan, mengingat dengan mengetahui motivasi dan persepsi wisatawan yang berkunjung ke daya tarik wisata tirta pemandian air panas kintamani, maka pihak pengelola mampu memberikan pelayanan yang sesuai dengan kebutuhan wisatawan nusantara dan nantinya diharapkan akan berujung pada kepuasan layanan yang mampu mendorong loyalitas wisatawan pada daya tarik wisata tirta pemandian air panas kintamani ini. Sedangkan permasalahan mengenai persepsi juga penting dilakukan agar pihak pengelola mengetahui bagaimana persepsi wisatawan terhadap daya tarik ini, yang nantinya mampu memberikan kontribusi pada perbaikan serta peningkatan pelayanan dan pengelolaan dikemudian hari.

Dalam tulisan ini akan dibahas mengenai tiga pernyataan dari masingmasing motivasi push and pull factor yang mendapatkan nilai tertinggi dan pernyataan yang mendapatkan nilai terendah serta akan dibahas mengenai persepsi wisatawan nusantara yang berkunjung ke Toya Devasya.

\section{METODE PENELITIAN}

Lokasi penelitian ini dilakukan di dua daya tarik wisata tirta pemandian air panas Kintamani yang ada di Kintamani yaitu di Toya Devasya yang terletak di Toya Bungkah, Desa Batur, Kecamatan Kintamani, Kabupaten Bangli, Provinsi Bali yang berjarak sekitar $90 \mathrm{Km}$ dari Bandara Ngurah Rai. 
Adapun variable yang diteliti yaitu, variable motivasi dan persepsi. Varibel motivasi yang dibagi menjadi dua sub variable, yaitu push factor dan pul factor. Faktor pendorong (push factor) meliputi: melepaskan diri dari kejenuhan lingkungan kerja (escape), kenyamanan (relaxation), gengsi atau gaya hidup (prestige), sosial interaksi (social interaction), suasana romantis (romance), keinginan menemukan diri sendiri (self-fulfilment), keinginan merealisasikan mimpi atau citacita (wish-fulfilment), meningkatkan kesehatan (health). Factor penarik (pull factor) meliputi : iklim dan suasana tempat, akses jalan dan kemudahan, lingkungan yang alami (pemandangan), kelengkapan fasilitas, biaya / tiket masuk, keunikan sumber air panas.

Persepsi wisatawan terhadap kualitas pelayanan yang dimaksud dalam penelitian ini adalah pandangan atau tanggapan dan penilaian wisatawan nusantara terhadap daya tarik wisata tirta pemandian air panas kintamani oleh Walgito 1996, yang diukur menggunakan variable-variabel seperti: tangible yang meliputi (attraction, accessibilities, amenities, ancillary) empathy, responsiveness, reliability, dan assurance.

Teknik pengumpulan data yang digunakan dalam penelitian ini adalah wawancara, observasi, dan kuesioner. Adapun teknik penentuan sampel yang bersifat purposive dan pengambilan sampel yang bersifat accidental sampling dan penentuan jumlah sampel yang mengunakan kuota sampling yang merupakan teknik penentuan sampel berdasarkan kebetulan, yaitu siapa saja yang secara kebetulan bertemu dengan peneliti dengan jumlah sampel 100 responden wisatawan nusantara.

Penelitian ini menggunakan analisis data secara deskriptif kualitatif dan deskriftif kuantitatif. Analisis deskriptif kualitatif yaitu gambaran yang disusun secara sistematis, aktual dan akurat mengenai fakta-fakta yang ada. Pada prinsipnya data kualitatif lebih cenderung berbentuk kata-kata (Arikunto, dalam penelitian Witarsanan, 2017). Sedangkan deskriptif kuantitatif adalah data yang berupa angka-angka yang dapat di klasifikasikan. Setelah semua data dibuat, maka peneliti akan menarik kesimpulan terhadap keseluruhan data tersebut, yang nantinya dijadikan sebagai kesimpulan penelitian.

\section{HASIL}

\section{Gambaran Umum}

Toya Devasya ini muncul ketika ditemukannya sumber air panas di pingir danau Batur oleh masyarakat sekitar banjar Toya Bungkah sekitar tahun 1990an yang terletak di suatu lahan milik perseorangan yang bernama Bapak I Ketut Marjana salah satu masyarakat desa Batur Tengah. Setahun setelah ditemukannya sumber air panas ini kemudin dipercaya untuk menghilangkan penyakit kulit dan menghilangkan pegal-pegal pada tubuh, sehingga pada saat itu banyak masyarakat yang datang kesana dengan tujuan metamba (berobat) di tempat munculnya air panas ini. Setiap orang yang datang kesana tidak diwajibkan untuk membayar, melaikan mereka hanya medana punia (sukarela). Semakin ramainya pengunjung yang datang kesana dari tahun ke tahun sumber air panas ini mulai dikelola oleh keluarga bapak I Ketut Marjana dengan melakukan pembangunan sebuah kolam yang masih sederhana. Seiring dengan berjalannya waktu pembangunanpembangunan fasilitas mulai dilakukan secara terus menerus sehingga pada tahun 2002 pemandian air panas ini diberi nama pemandian Tirta Sanjiwani yang kemudian dikelola secara kekeluargaan oleh keluarga Bapak I Ketut Marjana, melihat perkembangan jaman dan teknologi yang semakin canggih dari tahun ke ketahun terus mengalami perkembangan dan adanya perkembangan objek volcano tracking di kawasan Gunung Batur yang kunjungannya terus meningkat. 
Tabel 2. Motivasi (Push Factor/ Faktor

Pendorong) Wisatawan Berkunjung Ke Toya Devasya

\begin{tabular}{|c|c|c|c|}
\hline No & Pernyataan & $\begin{array}{l}\text { Jumlah } \\
\text { Skor }\end{array}$ & Rata-rata \\
\hline 1 & $\begin{array}{l}\text { Saya mengunjungi } \\
\text { daya tarik wisata tirta } \\
\text { ini untuk mendapat } \\
\text { suasana baru }\end{array}$ & 330 & 3,30 \\
\hline 2 & $\begin{array}{l}\text { Saya berkunjung ke } \\
\text { daya tarik wisata tirta } \\
\text { ini untuk melakukan } \\
\text { hal baru yang berbeda } \\
\text { dari pekerjaan sehari- } \\
\text { hari }\end{array}$ & 329 & 3,29 \\
\hline 3 & $\begin{array}{l}\text { Saya berkunjung ke } \\
\text { daya tarik wisata tirta } \\
\text { ini untuk melakukan } \\
\text { hal-hal yang dapat } \\
\text { membuat pikiran } \\
\text { menjadi tenang dan } \\
\text { santai }\end{array}$ & 344 & 3,44 \\
\hline 4 & $\begin{array}{l}\text { Saya berkunjung ke } \\
\text { daya tarik wisata tirta } \\
\text { ini untuk bersantai dan } \\
\text { membebaskan diri di } \\
\text { tempat yang indah dan } \\
\text { menarik }\end{array}$ & 337 & 3,37 \\
\hline 5 & $\begin{array}{l}\text { Saya berkunjung ke } \\
\text { daya tarik wisata tirta } \\
\text { ini untuk dapat } \\
\text { meningkatkan status } \\
\text { atau derajat social/ } \\
\text { mengikuti trend }\end{array}$ & 257 & 2,57 \\
\hline 6 & $\begin{array}{l}\text { Saya berkunjung ke } \\
\text { daya tarik wisata tirta } \\
\text { ini untuk berinteraksi } \\
\text { sosial dengan teman } \\
\text { sejawat dalam sebuah } \\
\text { kegiatan wisata }\end{array}$ & 306 & 3,06 \\
\hline 7 & $\begin{array}{l}\text { Saya berkunjung ke } \\
\text { daya tarik wisata tirta } \\
\text { ini untuk berinteraksi } \\
\text { dengan masyarakat } \\
\text { local }\end{array}$ & 292 & 2,92 \\
\hline 8 & $\begin{array}{l}\text { Saya berkunjung daya } \\
\text { tarik wisata tirta ini } \\
\text { bersama dengan } \\
\text { pasangan }\end{array}$ & 300 & 3,00 \\
\hline 9 & $\begin{array}{l}\text { Saya berkunjung ke } \\
\text { daya tarik wisata tirta } \\
\text { ini untuk melakukan } \\
\text { kegiatan olahraga atau } \\
\text { hobby yang dapat } \\
\text { menunjukkan jati diri } \\
\text { kita }\end{array}$ & 284 & 2,84 \\
\hline 10 & $\begin{array}{l}\text { Saya berkunjung ke } \\
\text { daya tarik wisata tirta } \\
\text { ini untuk mewujudkan } \\
\text { keinginan saya }\end{array}$ & 318 & 3,18 \\
\hline 11 & $\begin{array}{l}\text { Saya berkunjung ke } \\
\text { daya tarik wisata tirta }\end{array}$ & 316 & 3,16 \\
\hline
\end{tabular}

\begin{tabular}{ll}
\hline $\begin{array}{l}\text { ini untuk } \\
\text { meningkatkan } \\
\text { kesehatan tubuh }\end{array}$ & \\
\hline JUMLAH & $\mathbf{3 4 , 1 3}$ \\
\hline RATA-RATA & $\mathbf{3 , 1 0}$ \\
\hline
\end{tabular}

Sumber : Hasil penelitian tahun 2017

Berdasarkan pada tabel 2 mengenai motivasi (push factor/ faktor pendorong) skor 330 dengan rata-rata 3,30 mengenai pernyataan mengunjungi daya tarik wisata tirta ini untuk mendapat suasana baru dengan kategori sangat setuju. Motivasi berkunjung ke daya tarik wisata tirta ini untuk melakukan hal baru yang berbeda dari pekerjaan sehari-hari mendapat skor 329 dengan rata-rata 3,29 dengan kategori sangat setuju. Berkunjung ke daya tarik wisata tirta ini untuk melakukan hal-hal yang dapat membuat pikiran menjadi tenang dan santai mendapat skor 344 dengan rata-rata 3,44 dengan kategori sangat sangat setuju. Berkunjung ke daya tarik wisata tirta ini untuk bersantai dan membebaskan diri di tempat yang indah dan menarik memperoleh skor 337 dengan rata-rata 3,37 yang masuk kategori sangat sangat setuju. Berkunjung ke daya tarik wisata tirta ini untuk dapat meningkatkan status atau derajat social/ mengikuti trend memperoleh skor 257 dengan rata-rata 2,57 yang masuk kategori setuju. Berkunjung ke daya tarik wisata tirta ini untuk berinteraksi sosial dengan teman sejawat dalam sebuah kegiatan wisata memperoleh skor 306 dengan rata-rata 3,06 dengan kategori setuju. Berkunjung ke daya tarik wisata tirta ini untuk berinteraksi dengan masyarakat lokal memperoleh skor 292 dengan rata-rata 2,92 dengan kategori setuju. Berkunjung daya tarik wisata tirta ini bersama dengan pasangan memperoleh skor 300 dengan rata-rata 3,00 yang masuk kategori setuju. Berkunjung ke daya tarik wisata tirta ini untuk melakukan kegiatan olahraga atau hobby yang dapat menunjukkan jati diri kita memperoleh skor 284 dengan rata-rata 2,84 masuk kategori setuju. Berkunjung ke daya tarik wisata tirta ini untuk mewujudkan keinginan saya memperoleh 
skor 318 dengan rata-rata 3,18 masuk kategori setuju. Berkunjung ke daya tarik wisata tirta ini untuk meningkatkan kesehatan tubuh memperoleh skor 316 dengan rata-rata 3,16 yang masuk kategori setuju.

Tabel 3. Motivasi (Pull Factor/ Faktor Penarik) Wisatawan Berkunjung ke Toya Devasya

\begin{tabular}{|c|c|c|c|}
\hline No & Pernyataan & $\begin{array}{l}\text { Jumlah } \\
\text { Skor }\end{array}$ & Rata-rata \\
\hline 1 & $\begin{array}{l}\text { Suasana atau iklim pada } \\
\text { daya tarik wisata tirta ini } \\
\text { bagus untuk dinikmati }\end{array}$ & 347 & 3,47 \\
\hline 2 & $\begin{array}{l}\text { Lokasi daya tarik wisata } \\
\text { tirta ini mudah dijangkau } \\
\text { dengan berkendara }\end{array}$ & 311 & 3,11 \\
\hline 3 & $\begin{array}{l}\text { Ketersediaan informasi dan } \\
\text { petunjuk arah menuju daya } \\
\text { tarik wisata tirta ini sangat } \\
\text { jelas }\end{array}$ & 3,27 & 3,27 \\
\hline 4 & $\begin{array}{l}\text { Daya tarik wisata tirta ini } \\
\text { dilengkapi dengan } \\
\text { keindahan pemandangan } \\
\text { alam pegunungan }\end{array}$ & 350 & 3,50 \\
\hline 5 & $\begin{array}{l}\text { Ketersediaan fasilitas di } \\
\text { daya tarik wisata tirta ini } \\
\text { sangat lengkap }\end{array}$ & 315 & 3,15 \\
\hline 6 & $\begin{array}{l}\text { Tiket masuk yang } \\
\text { dikenakan di daya tarik } \\
\text { wisata tirta ini sangat } \\
\text { terjangkau }\end{array}$ & 318 & 3,18 \\
\hline 7 & $\begin{array}{l}\text { Sumber air panas yang ada } \\
\text { di daya tarik wisata tirta ini } \\
\text { unik karena berasal dari } \\
\text { Gunung Batur }\end{array}$ & 344 & 3,44 \\
\hline 8 & $\begin{array}{l}\text { Healing Spa yang ada di } \\
\text { daya tarik wisata tirta ini } \\
\text { sangat baik untuk } \\
\text { menyegarkan tubuh }\end{array}$ & 326 & 3,26 \\
\hline 9 & $\begin{array}{l}\text { Saya datang berkunjung ke } \\
\text { daya tarik wisata tirta ini } \\
\text { karena tertrik dengan } \\
\text { keindahan } \\
\text { pemandangannya }\end{array}$ & 343 & 3,43 \\
\hline 10 & $\begin{array}{l}\text { Daya tarik wisata tirta ini } \\
\text { lebih bagus dari tempat } \\
\text { wisata tirta lainnya di Bali }\end{array}$ & 306 & 3,06 \\
\hline 11 & $\begin{array}{l}\text { Fasilitas Spa yang } \\
\text { disediakan di daya tarik } \\
\text { wisata tirta ini sangat bagus } \\
\text { dan lengkap }\end{array}$ & 315 & 3,15 \\
\hline \multicolumn{2}{|c|}{ JUMLAH } & & 36,02 \\
\hline \multicolumn{2}{|c|}{ RATA-RATA } & & 3,27 \\
\hline
\end{tabular}

Berdasarkan pada tabel 3 mengenai motivasi (pull factorl faktor penarik). Suasana atau iklim pada daya tarik wisata tirta ini bagus untuk dinikmati mendapatkan skor 347 dengan rata-rata 3,47 yang masuk kedalam kategori sangat setuju. Lokasi daya tarik wisata tirta ini mudah dijangkau dengan berkendara mendapatkan skor 311 dengan rata-rata 3,11 yang masuk kedalam kategori setuju. Ketersediaan informasi dan petunjuk arah menuju daya tarik wisata tirta ini sangat jelas mendapatkan skor 327 dengan ratarata 3,27 yang masuk kedalam kategori setuju. Daya tarik wisata tirta ini dilengkapi dengan keindahan pemandangan alam pegunungan mendapatkan skor 350 dengan rata-rata 3,50 yang masuk kedalam kategori sangat setuju. Ketersediaan fasilitas di daya tarik wisata tirta ini sangat lengkap mendapatkan skor 315 dengan rata-rata 3,15 yang masuk kedalam kategori setuju. Tiket masuk yang dikenakan di daya tarik wisata tirta ini sangat terjangkau mendapatkan skor 318 dengan rata-rata 3,18 yang masuk kedalam kategori setuju. Sumber air panas yang ada di daya tarik wisata tirta ini unik karena berasal dari Gunung Batur mendapatkan skor 344 dengan rata-rata 3,44 yang masuk kedala kategori sangat setuju. Healing spa yang ada di daya tarik wisata tirta ini sangat baik untuk menyegarkan tubuh mendapatkan skor 326 dengan rata-rata 3,26 yang masuk kedalam kategori sangat setuju. Datang berkunjung ke daya tarik wisata tirta ini karena tertarik dengan keindahan pemandangannya mendapatkan skor 343 dengan rata-rata 3,43 yang masuk kedalam kategori sangat setuju. Daya tarik wisata tirta ini lebih bagus dari tempat wisata tirta lainnya di Bali mendapatkan skor 306 dengan rata-rata 3,06 yang masuk kedalam kategori setuju. Fasilitas Spa yang disediakan di daya tarik wisata tirta ini sangat bagus dan lengkap mendapatkan skor 315 dengan rata-rata 3,15 yang masuk kedalam kategori setuju. 
Tabel 4. Persepsi Wisatawan Nusantara yang Berkunjung ke Toya Devasya

\begin{tabular}{|c|c|c|c|c|}
\hline No & $\begin{array}{l}\text { Kwalitas } \\
\text { Pelayanan }\end{array}$ & Pernyataan & Skor & $\begin{array}{r}\text { Rata- } \\
\text { rata }\end{array}$ \\
\hline \multirow{9}{*}{1} & \multirow{9}{*}{ Tangible } & $\begin{array}{l}\text { Pemandangan yang ada } \\
\text { di daya tarik wisata tirta } \\
\text { ini sangat indah }\end{array}$ & 352 & 3,52 \\
\hline & & $\begin{array}{l}\text { Kegiatan wisata yang } \\
\text { bisa dilakukan di daya } \\
\text { tarik wisata tirta ini } \\
\text { bervariasi dan menarik }\end{array}$ & 326 & 3,26 \\
\hline & & $\begin{array}{l}\text { Ketersediaan informasi } \\
\text { dan petunjuk arah } \\
\text { menuju daya tarik } \\
\text { wisata ini sangat jelas }\end{array}$ & 324 & 3,24 \\
\hline & & $\begin{array}{l}\text { Ketersediaan jalan } \\
\text { utama atau alternative } \\
\text { menuju daya tarik } \\
\text { wisata tirta ini sangat } \\
\text { baik }\end{array}$ & 311 & 3,11 \\
\hline & & $\begin{array}{l}\text { Fasilitas kolam renang } \\
\text { yang ada di daya tarik } \\
\text { wisata tirta ini yang } \\
\text { sangatbersih dan bagus }\end{array}$ & 329 & 3,29 \\
\hline & & $\begin{array}{l}\text { Ketersediaan fasilitas } \\
\text { ruang ganti di daya tarik } \\
\text { wisata tirta ini sangat } \\
\text { memadai dan bersih }\end{array}$ & 330 & 3,30 \\
\hline & & $\begin{array}{l}\text { Ketersediaan dan } \\
\text { keberfungsian shower } \\
\text { pada ruang bilas di daya } \\
\text { tarik wisata tirta ini } \\
\text { sangat baik }\end{array}$ & 324 & 3,24 \\
\hline & & $\begin{array}{l}\text { Ketersediaan loket } \\
\text { pembayaran tiket masuk } \\
\text { sangat baik }\end{array}$ & 315 & 3,15 \\
\hline & & $\begin{array}{l}\text { Fasilitas restaurant dan } \\
\text { rumah makan yang ada } \\
\text { di daya tarik wisata tirta } \\
\text { ini bersih dan nyaman }\end{array}$ & 327 & 3,27 \\
\hline & & МLAH & 2.938 & 3,26 \\
\hline \multirow[t]{2}{*}{2} & \multirow[t]{2}{*}{ Emphaty } & $\begin{array}{l}\text { Pegawai di daya tarik } \\
\text { wisata tirta ini sopan } \\
\text { dan santun dalam } \\
\text { memberikan pelayanan }\end{array}$ & 335 & 3,35 \\
\hline & & $\begin{array}{l}\text { Pegawai selalu } \\
\text { mendengarkan keluhan } \\
\text { dari pengunjung }\end{array}$ & 320 & 3,20 \\
\hline JUM & AH & & 655 & 3,27 \\
\hline \multirow{4}{*}{3} & \multirow{4}{*}{$\begin{array}{l}\text { Responsi } \\
\text { veness }\end{array}$} & $\begin{array}{l}\text { Pegawai di daya tarik } \\
\text { wisata tirta ini bersikap } \\
\text { ramah dalam } \\
\text { memberikan pelayanan }\end{array}$ & 317 & 3,17 \\
\hline & & $\begin{array}{l}\text { Kecepatan dan } \\
\text { ketepatan pegawai } \\
\text { dalam menanggapi } \\
\text { keluhan pengunjung }\end{array}$ & 314 & 3,14 \\
\hline & & $\begin{array}{l}\text { Pegawai sangat cepat } \\
\text { dan tepat dalam } \\
\text { menaggapi permintaan } \\
\text { pengunjung terhadap } \\
\text { produk yang ditawarkan }\end{array}$ & 317 & 3,17 \\
\hline & & $\begin{array}{l}\text { Pegawai sangat cepat } \\
\text { dan tepat dalam }\end{array}$ & 325 & 3,25 \\
\hline
\end{tabular}

\begin{tabular}{|c|c|c|c|c|}
\hline \multicolumn{5}{|c|}{$\begin{array}{l}\text { pemberian informasi ke } \\
\text { pengunjug }\end{array}$} \\
\hline \multicolumn{3}{|c|}{ JUMLAH } & 1273 & 3,18 \\
\hline 4 & $\begin{array}{c}\text { Reliabilit } \\
y\end{array}$ & $\begin{array}{l}\text { Kehandalan atau } \\
\text { konsistensi pihak } \\
\text { pengelola daya tarik } \\
\text { wisata tirta dalam } \\
\text { memberikan } \\
\text { pelayanannya kepada } \\
\text { pengunjung sangat baik }\end{array}$ & 320 & 3,20 \\
\hline \multirow{4}{*}{5} & \multirow[b]{2}{*}{$\begin{array}{c}\text { Assuranc } \\
\mathrm{e}\end{array}$} & $\begin{array}{l}\text { Keberadaan life guard } \\
\text { (pengawal renang) } \\
\text { sangat tepat pada titik- } \\
\text { titik tertentu }\end{array}$ & 304 & 3,04 \\
\hline & & $\begin{array}{l}\text { Ketersediaan alat-alat } \\
\text { pengamanan seperti } \\
\text { pelampung dan papan } \\
\text { peringatan kepada } \\
\text { pengunjung sangat baik } \\
\text { dan jelas }\end{array}$ & 308 & 3,08 \\
\hline & \multicolumn{2}{|c|}{ JUMLAH } & 612 & 3,06 \\
\hline & \multicolumn{2}{|c|}{ JUMLAH KESELURUHAN } & 5598 & 3,22 \\
\hline
\end{tabular}

Sumber : Hasil penelitian tahun 2017

Berdasarkan pada tabel 4 mengenai persepsi wisatawan nusantara yang berkunjung ke Toya Devasya diatas dapat diketahui persepsi wisatawan nusantara yang berkunjung ke Toya Devasya yang dilihat dari 100 responden wisatawan nusantara. Pertama Persepsi wisatawan terhadap tangible yang merupakan kewujudan yang dapat dirasakan wisatawan yang dinilai dari pemandangan yang ada di daya tarik wisata tirta ini sangat indah yang mendapat skor 352 dengan rata-rata 3,52 yang masuk kedalam kategori sangat setuju, persepsi wisatawan terhadap kegiatan wisata yang bisa dilakukan di daya tarik wisata tirta ini bervariasi dan menarik mendapatkan skor 326dengan rata-rata 3,26 yang masuk kedalam kategori sangat setuju, persepsi wisatawan terhadap Ketersediaan informasi dan petunjuk arah menuju daya tarik wisata ini sangat jelas mendapatkan skor 324 dengan rata-rata 3,24 yang masuk kedalam kategori setuju, persepsi wisatwan terhadap ketersediaan jalan utama atau alternative menuju daya tarik wisata tirta ini sangat baik mendapatkan skor 311 dengan rata-rata 3,11 yang masuk kedalam kategori setuju, persepsi wisatawan terhadap fasilitas kolam renang yang ada di daya tarik wisata tirta ini yang 
sangatbersih dan bagus mendapatkan skor 329 dengan rata-rata 3,29 yang masuk kedalam kategori setuju, persepsi wisatawan terhadap ketersediaan fasilitas ruang ganti di daya tarik wisata tirta ini sangat memadai dan bersih yang mendapatkan skor 330 dengan rata-rata 3,30 yang masuk kedalam kategori sangat setuju, persepsi wisatawan terhadap ketersediaan dan keberfungsian shower pada ruang bilas di daya tarik wisata tirta ini sangat baik mendapatkan skor 324 dengan rata-rata 3,24 yang masuk kedalam kategori setuju, persepsi wisatawan terhadap ketersediaan loket pembayaran tiket masuk sangat baik mendapatkan skor 315 dengan rata-rata 3,15 yang masuk kedalam kategori setuju, persepsi wisatawan terhadap Fasilitas restaurant dan rumah makan yang ada di daya tarik wisata tirta ini bersih dan nyaman mendapatkan skor 327 dengan rata-rata 3,27 yang masuk kedalam kategori setuju, dengan keseluruhan perolehan skor tangible adalah 2.938 dengan rata-rata 3,26 yang masuk kedalam kategori sangat setuju. Kedua persepsi wisatawan terhadap emphaty yang merupakan seberapa baik karyawan dalam memberikan pelayanan yang dinilai dari pegawai di daya tarik wisata tirta ini sopan dan santun dalam memberikan pelayanan mendapatkan skor 335 dengan rata-rata 3,35 yang masuk kedalam kategori sangat setuju, persepsi wisatawan terhadap pegawai selalu mendengarkan keluhan dari pengunjung mendapatkan skor 320 dengan rata-rata 3,20 yang masuk kedalam kategori setuju, secara keseluruhan perolehan skor emphaty adalah 655 dengan rata-rata 3,27 yang masuk kedalam kategori sangat setuju. Ketiga persepsi wisatawan terhadap responsiveness yang merupakan daya tanggap karyawan dalam memberikan pelayanan yang dinilai dari pegawai di daya tarik wisata tirta ini bersikap ramah dalam memberikan pelayanan mendapatkan skor 317 dengan rata-rata 3,17 yang masuk kedalam kategori setuju, persepsi wisatwan terhadap Kecepatan dan ketepatan pegawai dalam menanggapi keluhan pengunjung mendapatkan skor 314 dengan rata-rata 3,14 yang masuk kedalam kategori setuju, persepsi wisatwan terhadap pegawai sangat cepat dan tepat dalam menaggapi permintaan pengunjung terhadap produk yang ditawarkan mendapatkan skor 317 dengan rata-rata 3,17 yang masuk kedalam kategori setuju, persepsi wisatawan terhadap pegawai sangat cepat dan tepat dalam pemberian informasi ke pengunjug mendapatkan skor 325 dengan rata-rata 3,25 yang masuk kedalam kategori setuju, secara keseluruhan perolehan skor responsiveness adalah 1.273 dengan ratarata 3,18 yang masuk kedalam kategori setuju. Keempat persepsi wisatawan terhadap realibility yang merupakan kehandalan atau konsistensi pihak pengelola yang dinilai dari kehandalan atau konsistensi pihak pengelola daya tarik wisata tirta dalam memberikan pelayanannya kepada pengunjung sangat baik mendapatkan skor 320 dengan ratarata 3,20 yang masuk kedalam kategori setuju. Kelima persepsi wisatawan terhadap assurance yang merupakan pelayanan keselamatan yang dinilai dari keberadaan life guard (pengawal renang) sangat tepat pada titik-titik tertentu mendapatkan skor 304 dengan rata-rata 3,04 yang masuk kedalam kategori setuju, persepsi wisatawan terhadap ketersediaan alat-alat pengamanan seperti pelampung dan papan peringatan kepada pengunjung sangat baik dan jelas mendapatkan skor 308 dengan rata-rata 3,08 yang masuk kedalam kategori setuju, secara keseluruhan perolehan skor assurance adalah 612 dengan rata-rata 3,06 yang masuk kedalam kategori setuju.

\section{PEMBAHASAN \\ Motivasi Push and Pull Factor Wisatawan Nusantara Berkunjung Ke Toya Devasya}

Berdasarkan dari hasil penelitian bahwa motivasi yang dominan mendorong wisatawan nusantara yang berkunjung ke 
Toya Devasya yang dilihat dari 100 responden wisatawan nusantara diantaranya, 1) Pernyataan berkunjung ke daya tarik wisata tirta ini untuk melakukan hal-hal yang dapat membuat pikiran menjadi tenang dan santai, 2) Berkunjung ke daya tarik wisata tirta ini untuk bersantai dan membebaskan diri di tempat yang indah dan menarik, 3) Mengunjungi daya tarik wisata tirta ini untuk mendapat suasana baru. Tiga pernyataan tersebut masuk kedakam kategori sangat setuju. dari tiga motivasi tersebut memang benar berkunjung ke Toya Devasya bisa membuat pikiran menjadi tenang, selain itu wisatawan juga bisa menikmati hangatnya air dan keindahan danau Batur yang dilengkapi dengan perbukitan yang menghijau yang menyebabkan tempat ini cocok untuk tempat bersantai yang dimana juga dapat menyebabkan wisatawan nusantara yang berkunjung kesini mendapatkan suasana baru yang belum pernah dirasakan sebelumnya. Hal tersebut diperkuat dengan hasil wawancara dari wisatawan nusantara yang berkunjung ke Toya Devasya.

"Saya berkunjung kesini dengan mendapatkan informasi dari media sosial dan kunjungan saya kesini baru pertama kali tujuan saya mengunjungi daya tarik ini adalah untuk mengisi liburan dan bersantai untuk mendapatkan suasana baru yang bisa membuat pikiran saya menjadi tenang."( Lilisaraswati, Jakarta,hasil wawancara 17 November 2017 di Toya Devasya)

Hal tersebut menunjukan bahwa motivasi yang mendorong (push factor) wisatawan nusantara yang berkunjung ke Toya Devasya untuk mendapatkan suasanan baru dan untuk mendapatkan halhal yang membuat pikiran menjadi tenang serta bersantai karena ingin terlepas dari kejenuhan dan untuk mengisi waktu libur yang mereka miliki. Hal ini dikarenakan dengan karakteristik wisatawan yang kebanyakan masih SMA/SMK yang dalam kesehariaannya yang bergelut pada mata pelajaran disekolah dan juga sebagai pekerja swasta yang dalam kesehariannya bergelut dengan pekerjaan. Sedangkan indikator terendah pada motivasi push factor adalah meningkatkan status atau derajat sosial/mengikuti trend dengan perolehan skor 257dengan rata-rata 2,57 yang merupakan skor paling rendah diantara motivasi push factor yang lainnya, pernyataan tersebut memang benar karena dari hasil wawancara dan hasil penyebaran kuesioner kepada wisatawan nusantara di Toya Devasya mengatakan bahwa tujuan berkunjung ke Toya Devasya adalah untuk membuat pikiran menjadi tenang, bersantai dan ingin mendapatkan suasana yang baru.

Berdasarkan dari hasil penelitian motivasi yang dominan menarik (pull Factor) yang dilihat dari 100 responden wisatawan nusantara yang berkunjung ke Toya Devasya indicator yang mendapatkan nilai tertinggi diantaranya. 1) Suasana atau iklim pada daya tarik wisata tirta ini bagus untuk dinikmati, 2) Daya tarik wisata tirta ini dilengkapi dengan keindahan pemandangan alam pegunungan, 3) Sumber air panas yang ada di daya tarik wisata tirta ini unik karena berasal dari gunung batur. Dari tiga pernyataan tersebut yang mendapatkan skor tertinggi dan masuk kategori sangat setuju. Toya Devasya yang memiliki iklim yang cukup dingin yang cocok untuk menikmati air panas dan suasana yang bagus dengan keindahan pemandangan alam pegunungan yang masih asri dan lestari yang tidak ada duanya yang dapat menarik minat wisatawan untuk berkunjung kesini dengan tujuan disamping dapat menikmati air panas wisatawan juga dapat menikmati keindahan alam pegunungan baik sebelum maupun sesudah melakukan kegiatan di Toya Devasya dan wisatawan juga bisa menikmatinya sambil menikmati air panas yang ada di Toya Devasya, apalagi sumber air panas yang dipercaya berasal dari Gunung Batur yang mengalir di celah- 
celah bebatuan Gunung Batur yang juga dapat dipercaya dapat menyegarkan tubuh yang dapat menarik minat wisatawan nusantara untuk berkunjung Toya Devasya. Hal tersebut diperkuat dengan hasil wawancara dari wisatawan nusantara yang berkunjung ke daya tarik wisata tirta pemandian air panas kintamani.

"Saya berkunjung ke daya tarik wisata tirta pemandian air panas Kintamani adalah untuk menikmati suasana keindahan danau dan gunung Batur dan mencoba air panas yang ada di Kintamani." ( Joe Wendra, Bogor, hasil wawancara 5 November 2017 Toya Devasya)

Hal tersebut menunjukan bahwa motivasi yang menarik (pull factor) wisatawan yang berkunjung ke daya tarik wisata tirta pemandian air panas Kintamani karena untuk menikmati suasana dan keindahan danau dan gunung Batur yang merupakan pemandangan yang tidak ada duanya yang bagus untuk dinikmati dan untuk menikmati air panas yang ada di Kintamani yang memiliki kualitas bagus yang dipercaya dapat menyegarkan tubuh. Sedangkan indikator terendah pada motivasi pull factor adalah 1) Daya tarik wisata tirta ini lebih bagus dari tempat wisata tirta lainnya di Balai dengan perolehan skor 306 yang rataratanya 3,06 merupakan skor paling rendah diantara motivasi pull factor yang lainnya.

\section{Persepsi Wisatawan Nusantara Yang Berkunjung Ke Toya Devasya}

Berdasarkan dari hasil penelitian yang dilakukan diketahui persepsi wisatawan nusantara yang berkunjung ke Toya Devasya dari 100 responden wisatawan nusantara perolehan skor tertinggi adalah adalah pada sub indikator tangible dengan perolehan skor 2.938 yang rata-ratanya 3,26 yang masuk kedalam kategori sangat setuju, atau juga dapat dikatakan sudah sangat baik, dan dalam indikator tangible penilaian yang tertinggi ada pada pernyataan pemandangan yang ada di daya tarik wisata tirta ini sangat indah dengan perolehan skor 352 yang rata-ratanya 3,52 yang tergolong kedalam kategori yang sangat setuju. Sehingga dari pernyataan tersebut bahwa persepsi wisatawan terhadap pemandangan yang ada di daya tarik wisata dapat dikatakan sangat baik. Pemandangan yang ada di daya tarik ini memang sangat bagus dan tidak ada duanya yang diamana pertama wisatawan dapat menikmati pemandangan gunung Batur dan yang kedua wisatawan dapat menikmati pemandangan yakni perpaduan antara danau Batur dengan kolam air panas yang berlatarkan perbukitan yang menghijau yang masih asri dan lestari. Hal terebut diperkuat dengan hasil wawancara kepada salah satu wisatawan nusantara yang berkunjung ke daya tarik wisata tirta pemandian air panas Kintamani.

"Saya sangat senang berkunjung kesini disamping air panas yang bagus disini saya juga dapat melihat keindahan danau dan gunung Batur sambil menikmati air panas."( Daniel, Bandung, hasil wawancara 18 November 2017 di Toya Devasya)

Jika dianalisis lebih lanjut pendapat ini memang benar, wisatawan yang berkunjung ke daya tarik wisata tirta pemandian air panas kintamani disamping dapat menikmati air panas alami yang bersumber dari gunung Batur wisatawan juga bisa menikmati pemandangan danau dan gunung Batur sambil menikmati air panas yang merupakan satu-satunya yang ada di Bali.

Sedangkan berdasarkan perolehan skor yang paling rendah pada variabel persepsi terdapat pada indikator assurance yang merupakan pelayanan keselamatan dengan perolehan skor 612 dengan ratarata 3,06 yang masuk kedalam kategori setuju, atau juga dapat diktakan baik, dan dalam assurance ada dua hal yang dinilai seperti: 1) Keberadaan life guard (pengawas renang) sangat tepat berada 
pada titik-titik tertentu yang perolehan skornya 304 dengan rata-rata 3,04 yang tergolong kedalam kategori setuju, 2) Ketersediaan alat-alat pengamanan seperti pelampung dan papan peringatan dengan perolehan skor 308 dengan rata-rata 3,08 yang masuk kedalam kategori setuju. Dapat dikatakan persepsi wisatawan terhadap assurance sudah baik.Hal ini diperkuat dengan hasil wawancara ke wisatawan nusantara yang berkunjung ke Toya Devasya

"Selama saya menikmati air panas di kolam pada daya tarik ini saya tidak melihat adanya pengawas renang (life guard) yang stanbay di kolam" ( Rio Yulianto, Bandung, hasil wawancara 18 November 2017 di Toya Devasya).

Hal tersebut menunjukan bahwa life guard tidak ada pada posisi yang sudah ditentukan, dan berdasarkan pada hasil observasi yang saya lakukan selama penelitian, keberadaan life guard tidak menetap pada posisi yang sudah ditentukan hal ini dikarenakan petugas yang ditugaskan sebagai life guard yang meninggalkan posisinya pada waktu wisatawan sedang menikmati air panas.

Berdasarkan dari seluruh pernyataan yang mengenai persepsi wisatawan nusantara yang dilihat dari 100 responden wisatawan nusantara yang berkunjung ke daya tarik wisata tirta pemandian air panas di Kintamani secara keseluruhan memrolehan skor 5.598 dengan rata-rata 3,22 yang dapat digolongkan kedalam kategori setuju. Maka dari pernyataan tersebut dapat dikatakan bahwa persepsi wisatawan terhadap kualitas pelayanan di Toya Devasya adalah baik.

\section{SIMPULAN}

Berdasarkan dari hasil penelitian yang dilakukan di Toya Devasya mengenai motivasi berkunjung dan persepsi wisatawan nusantara terhadap kualitas pelayanan daya tarik wisata tirta pemandian air panas di Kintamani
Kabupaten Bangli. Dapat disimpulkan motivasi dan persepsi seperti :

1. Motivasi yang mendorong (Push Factor)

a) Saya mengunjungi daya tarik wisata tirta ini untuk mendapat suasana baru

b) Saya berkunjung ke daya tarik wisata tirta ini untuk melakukan hal-hal yang dapat membuat pikiran menjadi tenang dan santai

c) Saya berkunjung ke daya tarik wisata tirta ini untuk bersantai di tempat yang indah dan menarik

2. Motivasi yang menarik (Pull Factor)

a) Suasana atau iklim pada daya tarik wisata tirta ini bagus untuk dinikmati

b) Daya tarik wisata tirta ini dilengkapi dengan keindahan pemandangan alam pegunungan

c) Sumber air panas yang ada di daya tarik wisata tirta ini unik karena berasal dari Gunung Batur

3. Persepsi wisatwan

Persepsi wisatawan nusantara terhadap kualitas pelayanan yang ada di Toya Devasya secara keseluruhan memperolehan skor 5.598 dengan rata-rata 3,22 yang dapat digolongkan kedalam kategori setuju atau dapat juga dikatakan baik. .

\section{SARAN}

Ada beberapa saran yang dapat diberikan setelah melakukan penelitian adalah sebagai berikut :

1. Saran kepada Pemerintah yang lebih tepatnya Dinas Kebudayaan dan Pariwisata Kabupaten Bangli lebih memperhitungkan keberadaan daya tarik wisata pemandian air panas Kintamani ini seperti, di bidang aksessibilitas, promosi, dan penataan lingkungan setempat.

2. Saran kepada kepada pihak pengelola Toya devasya agar tetap menjaga kelestarian pemandangan gunung dan danau Batur, seperti: 
mengajak karyawan dan masyarakat sekitar untuk bergotong royong sekali dalam satu bulan diareal gunung dan danau Batur demi menjaga kelestariannya dan penyediaan tong sampah pada titiktitik tertentu.

3. Saran ditunjukan kepada pihak pengelola Toya devasya untuk mengisi pagar pembatas untuk kolam yang berada di dekat danau sehingga wisatawan aman dan nyaman dalam melakukan aktivitas.

4. Saran bagi peneliti selanjutnya diharapkan dapat meneliti seperti : meneliti motivasi dan persepsi wisatawan mancanegara yang berkunjung ke daya tarik wisata tirta pemandian air panas Kintamani. 


\section{Kepustakaan}

Cooper, John Fketcher, David Gilbert and

Stephen Wanhill. (1995). Tourism,

Principles and Practice.

London:Logman.

Kusmayadi dan Endah Sugianto, 2000. Metodologi Penelitian Dalam

Bidang Kepariwisataan Jakarta:

PT Gramedia Pustaka Umum

Parasurama, zeithamen, Valeria.A Berry, Leonard.L 1998 'Amultiple-item Scale for Measuring Consumer Perception Or Service Quality" Internasional Journal of Service Quality,vol No1

Pitana I Gede, Gayatri Putu G. 2005. Sosyologi Pariwisata,yogjakarta: ANDY.

Sharply, R. 1994. Tourism, Tourist and Society. Cambridgeshire: ELM Publication.

Spllane James J. Dr. (1987). Ekonomi Pariwisata, Sejarah dan Prospeknya. Yogyakarta: Kanisius.

Suwantoro, Gamal. (2004). Dasar-dasar Pariwisata. Yogyakarta: Andi Offset..

Witarsana, Kadek. 2017. Motivasi Dan Persepsi Wisatawan Mancanegara Berwisata Alam Trekking Mountain Di Taman Wisata Alam Gunung Batur Bukit Payang. Denpasar. Jurusan Industri Perjalanan Wisata Universitas Udayana.

Yeni Baharidan, Ni Made. Darma Oka, I Made, 2014, Persepsi Wisatawan Mancanegara Terhadap Pelayanan Butler Di Akara Villas Kuta, jurnal vol.5 Denpasar : Sekolah Tinggi Pariwisata Bali International Denpasar. 